\title{
Helminth parasites of the pupfish Cyprinodon meeki (Pisces: Cyprinodontiformes), an endemic freshwater fish from North-Central Mexico
}

\author{
A. MARTÍNEZ-AQUINO ${ }^{1 *}$, R. AGUILAR-AGUILAR ${ }^{2}$
}

\author{
${ }^{1}$ Instituto de Biología, Universidad Nacional Autónoma de México, Apartado Postal 70-153, C.P. 04510, México, \\ E-mail: maandres@ibiologia.unam.mx; ${ }^{2}$ Facultad de Ciencias, Universidad Nacional Autónoma de México, Apartado \\ Postal 70-399, C. P. 04510, México. E-mail: raguilar@ibiologia.unam.mx
}

\begin{abstract}
Summary
A total of 21 pupfish Cyprindon meeki was collected from the spring Abraham González, Durango, Mexico. Seven helminth taxa were recovered: Salsuginus angularis, Posthodiplostomum minimum, Clinostomum complanatum, Bothriocephalus acheilognathi, Cyclustera cf. ralli, Atactorhynchus duranguensis and Spiroxys sp. Among them, B. acheilognathi and $A$. duranguensis were the most frequent and abundant species. The remaining species were rare and found at low mean abundance. The observed species richness, individual parasite abundance, and diversity were low at component community and infracommunity levels. These features are in accordance with those recorded for other freshwater fish species in the Nearctic part of Mexico. Host feeding habits, along with its role as intermediate host, are suggested as the main factors in determining the helminth community structure in this fish species.
\end{abstract}

Key words: Pupfish; Cyprinodon meeki; helminth community; Mexico

\section{Introduction}

The pupfish Cyprindon meeki Miller, 1976 is a freshwater species restricted to small springs in the Mezquital River drainage, in the state of Durango, North of Mexico (Espinosa et al., 1993; Miller et al., 2005). It is a generalist feeder and observations of the intestinal content in the studied specimens indicate that their diet mainly consist of algae and insects. This fish species is currently listed as at risk (Miller et al., 2005; World Conservation Monitoring Centre, 2007), and, probably because of its restricted distribution, its helminth fauna is poorly known. The only published record for C. meeki is a recently described species of acanthocephalan (Salgado-Maldonado et al., 2005). The aim of this note is to present the helminthological record of the pupfish, C. meeki in its current area of distri- bution, and to describe the helminth community structure of this host species in terms of taxonomic composition, species richness and diversity.

\section{Material and Methods}

A total of 21 adult specimens of Cyprinodon meeki (total length 20 to $43 \mathrm{~mm}$ ) were collected using nets in the spring Abraham González $\left(24^{\circ} 12^{\prime} 45^{\prime}\right.$ 'N; 104 $\left.31^{\circ} 48^{\prime \prime} \mathrm{W}\right)$. This spring is located in Northern Mexico, few kilometers east of Durango City, State of Durango. The fishes were taken alive to the laboratory and examined within 24 hours after capture using standard procedures. All the external surfaces, mouth, gills, eyes, viscera, including liver, kidney, gut, mesenteries, body cavity and musculature of each host were examined under a stereomicroscope. All helminths found in each fish were counted and then fixed with hot 4 $\%$ formalin. Monogeneans, digeneans and cestodes were stained with Mayer's paracarmine or Ehrlich's haematoxylin, dehydrated using a graded alcohol series, cleared in methyl salicylate, and whole-mounted. Nematodes were cleared with glycerin for light microscopy, and stored in $70 \%$ ethanol. Prevalence (percent infected) and mean intensity (mean number of parasites per infected fish) were calculated and used following Bush et al. (1997). To determine if sample size was sufficient to produce an accurate estimate of the pool of parasites, a species-richness sample effort curve was used. Helminth species were grouped as dominant (high prevalence and abundance) and rare (low prevalence and abundance) after an Olmstead-Tukey corner test of association (Steel \& Torrie, 1981). Numerical dominance was determined using the Berger-Parker dominance index (Southwood, 1978). Infracommunities were described by the mean number of parasite species, the mean number of individual helminths, and the mean value of the Brillouin diversity index. Infracommunities were 
compared qualitatively within the locality using the Jaccard similarity index, and quantitatively using the Morisita-Horn index, as calculated in Magurran (1988). Voucher specimens of all taxa were deposited in the Colección Nacional de Helmintos (CNHE), Instituto de Biología, Universidad Nacional Autónoma de México, Mexico City.

\section{Results}

A total of 92 individual helminths were collected. Seven helminth species were recovered: one monogenean, two digeneans, two cestodes, one nematode and one acathocephalan (Table 1). Four helminth species were recovered as larval stages: Clinostomum complanatum, Posthodiplostomum minimum, Cyclustera cf. ralli and Spiroxys sp.; the remaining three helminth species were found as adults, with Atactorhynchus duranguensis as the only specialist to C. meeki. The cestode Bothriocephalus acheilognathi was the most abundant species, accounting for about $46 \%$ of the collected worms, followed by $A$. duranguensis which accounted for $17 \%$. These two species showed the highest levels of infection reaching prevalence values higher than $30 \%$. However, only B. acheilognathi registered a value of mean intensity higher than 2 parasites per infected host. Infection site, number of infected fish, prevalence, a mean intensity of each helminth species are shown in Table 1.
All of the individual hosts were infected, but only $28.5 \%$ of the fishes harbour two or three helminth species. The total number of individual helminths of all species per host varied from 1 to 22 , with a mean number of $4.38 \pm 7.23$ individuals per host. The Olmstead-Tukey test showed that the intestinal worms, $B$. acheilognathi and A. duranguensis, were frequent (prevalence $>20.41 \%$ ) and abundant (abundance $>0.627$ ). The remaining species have low prevalence and abundance values (Table 1).

The helminth infracommunities were species-poor. Most infracommunities were composed by only one species; four of them had two helminth species, and only two had a maximum of three species. The mean number of species per host was $1.38 \pm 0.67$. A large number of hosts $(40 \%)$ were parasitized by a single species (the acanthocephalan A. duranguensis). The Brillouin index for all infracommunities varied from 0 to 0.682 , with a mean diversity value of $0.132 \pm 0.234$, while the Berger-Parker dominance index values varied from 0.5 to 1 , with a mean of $0.92 \pm$ 0.147 . For comparative purposes, we calculate the Brillouin index for the six infracommunities with at least two species, which varied from 0.189 to 0.682 , with a mean diversity value of $0.462 \pm 0.191$, and the Berger-Parker dominance index values varied from 0.5 to 0.929 , with a mean of $0.721 \pm 0.139$. Most of these assemblages were dominated by the cestode $B$. acheilognathi. The helminth infracommunities with at least two species displayed a low

Table 1. Helminth parasites of the pupfish Cyprinodon meeki in Abraham Gónzalez spring, Durango, Mexico ( $\mathrm{n}=21)$

\begin{tabular}{lcccccc}
\hline & & Number & & & \\
& Infection & of hosts & Prevalence & Mean intensity & CNHE \\
Helminth & site(s) & infected & $(\%)$ & \pm SD & No. \\
\hline
\end{tabular}

\section{Monognea}

$$
\text { Salsuginus angularis }
$$

G

\author{
$\mathrm{Bc}, \mathrm{L}, \mathrm{M}$
}

4

L

1

23

5

$2 \pm 2.39$

13

$6003-6005$

Posthodiplostomum minimum

Cestoda

$$
\text { Bothriocephalus acheilognathi }
$$

I

7

33

$6.14 \pm 7.87$

6002

Larval Cestoda

Cyclustera cf. ralli

M

1

5

1

6007

Larval Nematoda

Spiroxys sp.

M

4

19

$1.5 \pm 0.58$

6000

Acanthocephala

Atactorhynchus duranguensis

I

10

48

$1.6 \pm 0.97$

6009

$\mathrm{Bc}=$ body cavity $\mathrm{G}=$ gills; $\mathrm{I}=$ intestine $; \mathrm{L}=$ liver; $\mathrm{M}=$ mesentery 
level of similarity. The corresponding Jaccard index varied from 0 to 0.667 (mean of $0.25 \pm 0.192$ ) and the MorisitaHorn index varied from 0 to 0.934 (mean of $0.302 \pm$ $0.361)$.

\section{Discussion}

Most helminth species parasitizing C. meeki were larval stages. All these helminths have previously been recorded for diverse freshwater fish species in Central Mexico (Salgado-Maldonado, 2006; Pérez-Ponce de León et al., 2007), and with the exception of $C$. cf. ralli, have also been found parasitizing to Characodon audax in the neighbor spring El Toboso (Martínez-Aquino et al., 2007). The remaining helminth species fall into three different categories: one generalist (Salsuginus angularis), one introduced (B. acheilognathi) and one specialist species (A. duranguensis). The monogenean $S$. angularis has been reported in cyprinodontiform fishes of Canada and United States, and has recently been recorded parasitizing goodeid fishes in Mexican waters (Mendoza-Palmero, 2007). The tapeworm $B$. acheilognathi is an introduced species widely distributed in freshwater fishes of Mexico (Gutiérrez-Cabrera et al., 2005; Salgado-Maldonado, 2006). The present record of this parasite in the endemic and endangered pupfish $C$. meeki, as well as in a sympatric population of Gambusia senilis (unpublished data, CNHE No. 6001), might be a factor for the conservation of the host, since that some authors consider it as a potential threat for native freshwater fishes, because its abundance and pathogenicity (Salgado-Maldonado and Pineda-López, 2003).

The helminth species herein recorded for C. meeki are not very different from the species found in other cyprinodontiform fishes in Central and Northern Mexico (Peresbarbosa-Rojas et al., 1994; Pérez-Ponce de León et al., 2000; Martínez-Aquino et al., 2004, 2007; Sánchez-Nava et al., 2004), and even from other fish species such as the atherinomorphs (Espinosa-Huerta, et al., 1996; Astudillo-Ramos and Soto-Galera, 1997). This can be explained for the nature of the bodies of water where these fishes inhabit, conformed mainly by endorreic springs and lakes were many allogenic species are transported by fish-eating reptiles and birds.

Because of its endangered status, no additional samples of C. meeki were taken. For this reason, the helminth community structure described in this work corresponds to a particular point in time and space. The helminth community of $C$. meeki exhibits low values of species richness at both, the component community and infracommunity levels, and it is in accordance to those recorded for other freshwater fishes in the Nearctic part of Mexico as Alloophorus robustus, Goodea atripinnis, Allotoca diazi, Chapalichthys encaustus, Characodon audax, Chirostoma attenautum and Chirostoma humboldtianum (EspinosaHuerta et al., 1996; Astudillo-Ramos and Soto-Galera, 1997; Rojas et al., 1997; Pérez-Ponce de León et al., 2000; Martínez-Aquino et al., 2004, 2007).

A second characteristic shared among the helminth com- munity of $C$. meeki, and those exhibited by other freshwater fishes occurring in Central and North-Central Mexico, is the numerical dominance by a few numbers of species. However, unlike previous records (Pérez-Ponce de León et al., 2000; Martínez-Aquino et al., 2004, 2007) the generalist larval trematode $P$. minimum was not the dominant species in C. meeki. In this study, the specialist acanthocephalan $A$. duranguensis seems to be the only dominant species at both, infracommunity and component community levels.

Except for some cases as the goodeid Characodon lateralis, where the poorest helminth communities have been recorded (Mejía-Madrid et al., 2005; Martínez-Aquino et al., 2007), the data suggest that the helminth composition, and the process involved in the structure of helminth communities are common in those fishes occurring in water bodies of Central and Northern Mexico. This work confirms the depauperate and dominated nature of the helminth assemblages of fishes inhabiting in epicontinental waters in the Nearctic part of Mexico (Espinosa-Huerta et al., 1996; Rojas et al., 1997; Choudhury and Dick, 2000; Pérez-Ponce de León et al., 2000; Martínez-Aquino et al., 2004, 2007; Sánchez-Nava et al., 2004), and also suggest that host feeding habits, along with its role as intermediate host for allogenic helminth species, seem to be the main factors determining the helminth community structure. Additional studies for other fish species are necessary to establish patterns and processes involved in the conformation of these helminth assemblages, considering host diet, invasion for exotic helminth species, availability of intermediate hosts and environmental characteristics.

\section{Acknowledgments}

We thank John Lyons for identification of hosts and Carlos Mendoza-Palmero for identification of the monogenean. Thanks also to Norman Mercado-Silva, Héctor Espinosa, Edgar Ávila-Luna, Henry L. Bart Jr., Guillermina Cabañas, and Mirza P. Ortega for their technical assistance in the field and laboratory. AMA thanks CONACyT for scholarship to accomplish his MsC degree. RAA was supported by a Postdoctoral Fellowship from Dirección General de Asuntos del Personal Académico (DGAPA), UNAM, México.

\section{References}

Astudillo-Ramos, L., Soto-Galera E. (1997): Estudio helmintológico de Chirostoma humboldtianum y Girardinichthys multiradiatus capturados en el Lerma. Zoología Informa, 35: 53 - 59 (in Spanish)

Bush, A.O., Lafferty, K. D., Lotz, J. M., Shostak, A. W. (1997): Parasitology meets ecology on its own terms: Margolis et al. revisited. J. Parasitol., 65: 667 - 669

ChOudhury, A., Dick, T. (2000): Richness and diversity of helminth communities in tropical freshwater fishes: Empirical evidence. J. Biogeogr., 27: 935 - 956

Espinosa, P. H., Gaspar, M. T., Fuentes, M. P. (1993): 
Listados faunísticos de México. III. Los peces dulceacuícolas mexicanos. Instituto de Biología, Universidad Nacional Autonóma de México, México, D. F. (in Spanish) Espinosa-Huerta, E., García-Prieto, L., PÉrez-Ponce DE LEÓN, G. (1996): Helminth community structure of Chirostoma attenuatum (Osteichthyes: Atherinidae) in two Mexican lakes. Southwest. Nat., 41: $288-292$

Gutiérrez-Cabrera, A. E., Pulido-Flores, G., MonKs, S., GAYTÁn-OYARZún, J. C. (2005): Presencia de Bothriocephalus acheilognathi Yamaguti, 1934 (Cestoidea: Bothriocephalidae) en peces de Metztitlán, Hidalgo, México. Hidrobiológica, 15: 283 - 288 (in Spanish)

MAGURRAN, A. (1998): Ecological diversity and its measurement. Croom Helm, London

Martínez-Aquino A., SAlgado-Maldonado, G., Aguilar-Aguilar, R., CABAÑas-Carranza, G., MendozA-PALMERO, C. (2007): Helminth parasite communities of Characodon audax and C. lateralis (Pisces: Goodeidae), endemic freshwater fishes from Durango, Mexico. Southwest. Nat., 52: 125 - 130

MARTÍneZ-Aquino A., SAlgado-MaldonAdo, G., Aguilar-Aguilar, R., CABAÑas-Carranza, G., OrtegA-Olivares, M. P. (2004): Helminth parasites of Chapalichthys encaustus (Pisces: Goodeidae), an endemic freshwater fish from Lake Chapala, Jalisco, Mexico. J. Parasitol., 90: 889 - 890

MejíA-MADRID, H. H., DomíngueZ-DomíngueZ, O., PÉreZ-Ponce De LEÓN, G. (2005): Adult endohelminth parasites of Goodeinae (Cyprinodontiformes: Goodeidae) from México with biogeographical considerations. Comp. Parasitol., 72: $200-211$

MendozA-PALMERO, C. A. (2007): Monogéneos parásitos de peces de la subfamilia Goodeinae (Pisces: Cyprinodontiformes) con un análisis de su distribución geográfica. MSc. Thesis, Posgrado en Ciencias Biológicas, Universidad Nacional Autónoma de México (in Spanish)

Miller, R. R., Minckley, W. L., NORRIS, S. M. (2005): Freshwater Fishes of México. The University of Chicago Press, Chicago

Peresbarbosa-Rojas, E., Pérez-Ponce De León, G., GARCÍA-PRIETO, L. (1994): Helmintos parásitos de tres especies de peces (Goodeidae) del Lago de Pátzcuaro, Michoacán. Anales Inst. Biol. Univ. Nac. Autón. México, Ser. Zool. 65: 201 - 204 (in Spanish)

Pérez-Ponce De León, G., García-Prieto, L., MENDOZA-GARFIAS, B. (2007): Trematode parasites (Platyhelminthes) of wildlife vertebrates in Mexico. Zootaxa, 1534: 1 - 247

Pérez-Ponce De León, G., García-Prieto, L., LeóNRÈGagnon, V., Choudhury, A. (2000): Helminth communities of native and introduced fishes in Lake Pátzcuaro, Michoacán, México. J. Fish Biol., 57: 303 - 325

Rojas, E., PÉrez-Ponce De León, G., García-Prieto, L. (1997): Helminth community structure of some freshwater fishes from Patzcuaro, Michoacan, Mexico. Trop. Ecol., 38: $129-131$

SAlgado-Maldonado, G. (2006): Checklist of helminth parasites of freshwater fishes from Mexico. Zootaxa, 1324: $1-357$

SAlgado-MaldonAdo, G., PInEdA-LÓPEZ, R. F. (2003): The Asian fish tapeworm Bothriocephalus acheilognathi: A potential threat to native freshwater fish species in Mexico. Biol. Inv., 5: $261-268$

SAlgado-MaldonAdo, G., Aguilar-Aguilar, R., CABAÑAS-CARRANZA, G. (2005): Atactorhynchus duranguensis n. sp. (Acanthocephala: Atactorhynchinae) from Cyprinodon meeki (Pisces: Cyprinodontidae) near Durango, Mexico. Syst. Parasitol., 60: 205 - 209

SÁnchez-Nava, P., SAlgado-Maldonado, G., SotoGALERA, E., JAIMES-CRUZ, B. (2004): Helminth parasites of Girardinichthys multiradiatus (Pisces: Goodeidae) in the upper Lerma River sub-basin, Mexico. Parasitol. Res., 93: $396-402$

Southwood, T. R. (1978): Ecological methods, $2^{\text {nd }}$ ed. Chapman and Hall, London

STEEL, R. G. D., TORRIE, J. H. (1981): Principles and procedures of statistics: a biometrical approach, second edition. McGraw-Hill International Book Company, London World CONSERVATION MONITORING CENTRE (2007): Cyprinodon meeki. In IUCN Red List of Threatened Species. ww.iucnredlist.org/search/details.php/6159/summ 